\title{
“How Do We Teach Them to Read If They Can't Pay Attention?": Change in Literacy Teaching Practice through Collaborative Learning
}

\author{
SHELLEY MURPHY \\ OISE/University of Toronto
}

\begin{abstract}
A significant number of students with Attention Deficit Hyperactivity Disorder (ADHD) struggle with their literacy learning (Cain \& Bignell, 2014). This paper investigates the experiences of a group of teachers who participated in a collaborative learning community devoted to improving their literacy teaching for students with characteristics of ADHD. Five elementary general education classroom teachers were interviewed and observed while in the midst of professional development (PD) meetings and again six months after formal PD had stopped. Findings illustrate that the PD resulted in sustained improvements in both teachers' sense of self-efficacy as literacy teachers and their literacy teaching practices. The PD also helped to contribute to more feelings of compassion and lower levels of stress associated with teaching students with ADHD.
\end{abstract}

It is estimated that there is at least one student with attention deficit hyperactivity disorder (ADHD) in most general education classrooms in North America (American Psychiatric Association, 2013; Morrow et al., 2012). Research suggests these students are at high risk for significant difficulties with their reading and writing (Breslau et al., 2009; Fletcher \& Wolfe, 2008; Tannock, 2007). On the other hand, there is ample research to suggest that students with ADHD can be successful within the general education classroom if teachers know how to differentiate instruction for them (Harjacher, Roberts, \& Merrill, 2006; Martinussen, et al., 2011). However, teachers cite lack of quality professional learning on the topic of ADHD as one of the major barriers to providing effective literacy instruction for students (Rush \& Harrison, 2008; Westling, 2010). The majority of the documented studies on professional development (PD) for teachers on the topic of ADHD focus on teachers' knowledge and attitudes, and rely on teacher selfreport measures of these immediately following in-service training (Jones, Daley, Hutchings, Bywater, \& Eames, 2008; Kos et al., 2006). These studies show that professional development programs can lead to improvement in teacher's knowledge about ADHD, but they provide limited insight into teachers' detailed responses to the program or subsequent changes in their teaching practice with students. As Hargreaves and Fullan (1992) suggest, the true test of whether training contributes to practice is the degree to which teachers implement new strategies on a consistent basis and over an extended period of time.

The research literature indicates that teachers benefit most from PD experiences that are conducted collaboratively, occur over an extended period of time, include 
opportunities for teachers to receive coaching and feedback, and involve teacher-centered active forms of learning (Desimone et al., 2002; Leko \& Brownell, 2009). Yet, few studies have consulted teachers about their detailed experiences in PD that includes these aspects, particularly on the topic of supporting students with ADHD. Through this study, I sought to improve our understanding of such experiences. This paper reports on the experiences of teachers in Ontario, Canada who were involved in professional development that was constructed as a learning community.

Specifically, this paper explores the perspectives and experiences of five elementary general classroom teachers from one large urban school as they participated in a collaborative learning community devoted to improving their literacy teaching for students with Attention Deficit Hyperactivity Disorder (ADHD). Although much has been written on teacher involvement in learning communities (e.g., Butler et al., 2012; Schechter \& Ganon, 2012; Wenger, 1998), there is limited information on the details of how teachers experience them on the topic of supporting students with ADHD in their literacy learning. This qualitative study was designed as a response to this gap in the literature. Specifically, one central question guided this research: How did teachers' participation in PD organized as a collaborative learning community (CLC) influence their literacy teaching for students with characteristics of ADHD?

\section{Literature Review}

While approximately 5\% of school-age children have ADHD (American Psychiatric Association, 2013; Barkley, 2013; Rogers, Wiener, Marton, \& Tannock, 2009), studies have demonstrated that symptoms of ADHD are expressed across a continuum of risk (Levy, Hay, McStephen, Wood, \& Waldman, 1997; Polderman et al., 2007). Teachers will have students who have characteristics of ADHD, such as inattentiveness or hyperactivity, but do not have a diagnosis of ADHD. Regardless of whether students have been formally identified with ADHD or not, if they display inattention and/or hyperactivity they are likely at high risk for poor academic achievement and school dropout (Breslau et al., 2009; Currie \& Stabile, 2006; Fletcher \& Wolfe, 2008). Particularly, children with ADHD also often have significant difficulties with their reading and writing (Cain, \& Bignell, 2014; Tannock, 2007).

According to Tannock (2007), longitudinal epidemiological surveys in Canada and the US show that children with ADHD, particularly those with the inattentive type, have 8 to $10 \%$ lower achievement scores in reading. Studies show that deficits in executive functions, particularly working memory, along with slower processing speeds in many children with ADHD contribute to these difficulties (Katz, Brown, Roth, Beers, 2011; Tannock, 2007).

Although children with characteristics of ADHD exhibit a range of reading profiles, past studies suggest that between 25 and 40\% of children with ADHD meet the criteria for reading disorders (Caroll, Maughan, Goodman, \& Meltzer, 2005; Tannock \& Brown, 2000). Furthermore, Carroll et al. (2005) found that the association between ADHD and reading difficulties primarily reflected increased symptoms of inattention. It is interesting to note that students with ADHD who do not have coexisting reading 
disorders have also been found to exhibit relative weaknesses in reading performance, particularly in text reading rate, accuracy and reading comprehension (Cain, \& Bignell, 2014; Ghelani, Sidhu, Jain, \& Tannock, 2004; Sesma et al., 2009). In general, difficulties in literacy acquisition associated with ADHD can be classified into three areas: weaknesses in text recall and comprehension (Sesma, et al., 2009), weaknesses in written expression, and weaknesses in language functioning (Martinussen et al; 2005).

Teachers need a good understanding of the types of educational approaches that can support the literacy learning of students with characteristics of ADHD (Martinussen, Tannock, \& Chaban, 2011). However, studies report that teachers have limited knowledge of ADHD, its effects on school functioning, and appropriate adaptive or inclusive strategies (Kos, Richdale, \& Hay, 2006; Martinussen, Tannock, Chaban, McInnes, \& Ferguson, 2006). This is due, in part, to a lack of opportunity for professional learning in this area (Barbaresi \& Olsen, 1998; Bussing, Gary, Leon, Wilson Garvan, \& Reid, 2002; Jerome, Gordon, \& Hustler, 1994; Tannock, 2007). Martinussen et al. (2011) found that teachers feel ill-equipped to support their students with characteristics of ADHD. This is of considerable concern given that effective teaching for all students requires knowledge about how students learn differently and the kinds of teaching strategies that are most effective for different kinds of learning (Barkley, 2012; DarlingHammond et al., 2005; Jordan, Schwartz, \& McGhie-Richmond, 2009). Without this knowledge, well-meaning but ill-prepared teachers are at risk of giving up on students whom they have not yet learned to teach (Darling-Hammond et al., 2005). DuPaul and Stoner (2003) assert, "it is quite humbling to realize that although our understanding of ADHD has greatly advanced over the last decades, children with this disorder continue to encounter significant difficulties in succeeding in our schools" (p. 236). Lack of opportunity for professional learning on this topic appears to contribute significantly to this problem.

The majority of studies looking at PD for teachers on the topic of ADHD examined didactic, 1- to 2-hour, professional development workshops (e.g. Bos, Nahmias, \& Urban, 1997; Jones et al., 2008). There is little empirical data to indicate that this type of PD is effective in enhancing the skills of educators. Professional consensus has emerged about particular characteristics of "high quality" professional development and the features associated with improvements in student learning (Desimone et al., 2002; Opfer and Pedder, 2011). This study consults teachers about their professional development experience of learning how to improve their literacy support for students with characteristics of ADHD. The professional development was co-constructed with the participants and was organized with the characteristics of high quality professional development in mind.

\section{Theoretical Framework}

A social constructivist theoretical perspective informed the design of this study. Social constructivist theories (e.g. Dewey, 1938/1997; Vygotsky, 1978) place a strong emphasis on the context and social experiences of individuals. Research suggests that professional development models that focus on teacher knowledge and inquiry are 
superior to those that deliver expert knowledge and expect teachers to adopt specific practices (Lytle, Belzer, \& Reumann, 1992). Viewed through a social constructivist lens, teachers, as learners, are not empty vessels to be filled with knowledge imparted by others. Rather, learning is a process through which learners construct their knowledge by modifying or revising existing ideas as a result of coming into contact with the ideas of others (Bransford, Brown, \& Cocking, 1999; Bruner, 1966; Vygotsky, 1986). As is the case with students in the classroom, teachers' learning comes from thinking through and often struggling with problems and situations to arrive at new understandings. These understandings are built on learners' existing views. The learner interacts in a very active way with ideas and experiences, rather than just passively taking in facts or memorizing data (Bransford et al., 1999). In this study, the teachers explored their pre-existing views and experiences along with the ideas and experiences of others' within the group as they actively learned to make sense of new ideas and understandings together.

\section{Methodology}

Qualitative methods were chosen as a research approach because I was primarily interested in a rich and detailed understanding of teachers' experiences. Furthermore, I felt it was the most appropriate means of exploring the complex world of teaching and teacher learning from the perspectives of teachers themselves (Punch, 2009). As Corbin and Strauss (2007) suggest, perhaps the most important reason that a researcher chooses to do qualitative inquiry is so that we may view the world vicariously from the perspectives of the research participants, with the hope of developing empirical knowledge from these discoveries.

For my study, I employed a multiple case study approach which includes more than one case, and the analysis is performed at two levels: within each separate case and across all of the cases (Yin, 2011). The experiences and perspectives of each of the five individual elementary teachers formed a case study and the five cases were compared and contrasted. I chose this approach because I wanted to present a rich and vivid understanding of teachers' individual experiences within the CLC (Creswell, 1998; Merriam, 2009). I conducted the analysis across their experiences with the hope of providing an understanding of their professional learning experience more generally.

\section{Participants}

The five participants in this study were all elementary classroom teachers from a junior and senior public school in a large urban center in Ontario, Canada. An open invitation was sent to all teachers within the school inviting them to attend an informational session outlining the details of my proposed study. The criteria for selecting the participants included being an elementary general education classroom teacher, having students with characteristics of ADHD in the classroom at the time of the study, and being interested in improving knowledge about ADHD and literacy teaching practices for students with characteristics of ADHD. The first five teachers to respond were chosen for the study. All of the participants were general education teachers of 
grades ranging from kindergarten to Grade 3. The participants had from 5 to 20 years of teaching experience. Pseudonyms have been used for all participants.

Table 1

Teacher Background Information

\begin{tabular}{lcccc}
\hline $\begin{array}{l}\text { Name of } \\
\text { Participant }\end{array}$ & $\begin{array}{c}\text { Number of } \\
\text { Years } \\
\text { Teaching }\end{array}$ & Grade (s) & $\begin{array}{c}\text { Prior PD on } \\
\text { the Topic of } \\
\text { ADHD }\end{array}$ & $\begin{array}{c}\text { No. of Students with } \\
\text { ADHD/Characteristics } \\
\text { of ADHD }\end{array}$ \\
\hline May & 5 & Grades $1 / 2$ & No & 2 \\
Wendy & 9 & Grade 3 & No & 5 \\
Connie & 10 & Kindergarten & No & 2 \\
Kathy & 18 & Grade 1 & No & 5 \\
Danielle & 20 & Kindergarten & No & 2 \\
\hline
\end{tabular}

\section{Professional Development Model}

Participants were invited to participate in this study and a professional development experience that would be focused on improving their literacy teaching for their students with characteristics of ADHD. Although the general topic (ADHD and literacy teaching) for the PD was chosen ahead of time, the format and detailed content of the PD was not. The intention was to have these details come about through an emergent and co-constructed process with the participants. This process began with an initial interview with each participant; each of them was asked how they would like the PD to be structured and what specific content they wanted included. This would give the participants an opportunity to establish their own learning goals based on areas of interest, perceived needs, and the realities of their classroom contexts.

Structure. In their initial interviews, participants communicated that they were interested in having a collaborative learning community type professional development. Specifically they were interested in: working closely alongside their colleagues, having control over the direction of the PD, having site-based PD that was grounded in day-today teaching practice, and having several meetings over time that were integrated within the work day (lunch hour). They wanted opportunities to try out new strategies in their classrooms and to come back to the group to share, discuss, and receive feedback from each other. They were also interested in observing each other's literacy teaching with students with characteristics of ADHD. Finally, they were interested in having input from me, the principal investigator, as a source of resources in the form of up-to-date research and literature (articles, books etc.) on ADHD and literacy teaching strategies.

Content. During their initial interviews, participants were asked about the specific content areas they were interested in focusing on within their PD. Participants 
communicated that they were interested in: a general overview of the nature of ADHD (causes, typical symptoms, how identified, etc.), the cognitive component of ADHD and educational implications (i.e. what is happening in the brain of a student with ADHD that results in inattention, hyperactivity, impulsiveness), specific ways to support students with characteristics of ADHD and their literacy learning (reading and writing), opportunities to discuss students from their own classrooms as "real world portraits of children with characteristics of ADHD" and to discuss appropriate responses; strategies for the behavioral aspects associated with ADHD. They were also interested in having access to current research articles and books on the topic of ADHD.

The structure and content of the CLC was flexible, fluid, and based on participants' ongoing and changing needs. In the end, the participants decided to meet eight times over a five-month period - approximately once every 2 to 3 weeks during their lunch hours. The majority of meetings took place in one of the participants' classrooms to give them an opportunity to become familiar with the structure and layout of each other's teaching contexts.

Each CLC meeting began with a check-in. Participants shared a few statements about their most relevant experiences within the weeks since the last meeting. A short discussion on current literature and research would take place based on the weeks' reading. Teachers shared, for example, details about attempting new strategies, about successes or challenges they were having with students, about student progress, and about frustrations and goals. Following this, one participant would present a student case study. During the remaining time, the participants discussed ideas and strategies for supporting this student. Each meeting ended with a discussion about possible modifications needed to the format, timetabling, or focus of the CLC. In table 2, there is an overview of the general focus for each CLC meeting based on the participants stated learning goals.

\section{My Role in the CLC}

My role within the CLC was a dual one. I took part in each of the CLC meetings as both a participant in and observer of the situation (Punch, 2009). As an observer of the situation my role was to gather data. Teachers' sharing of their experiences, thoughts, ideas, and self reflections during meetings served as both a means of professional growth for them and a means of data gathering for the study. By being a participant observer I was able to gather rich descriptions and understandings of participants' experiences within the CLC. As a participant in the meetings, my in-group role (Hargreaves, 1967) was to provide resources and information necessary for the participants to pursue their goals, and to join in on discussions and share my knowledge, experiences, observations, and suggestions. As such, I was a co-constructor of the CLC process along with the other participants. My presence acted as somewhat of a catalyst for the participants' growth and development. 
Table 2

Overview of Collaborative Learning Community Meetings

\begin{tabular}{|c|c|c|}
\hline Date of Session & Location & Topics \\
\hline $\begin{array}{l}\text { February 24, } \\
2010\end{array}$ & $\begin{array}{l}\text { Speech and } \\
\text { Language Room }\end{array}$ & $\begin{array}{l}\text { General overview of ADHD (typical } \\
\text { characteristics, identification criteria, causes, } \\
\text { educational implications of ADHD); research } \\
\text { informed strategies }\end{array}$ \\
\hline March 9, 2010 & $\begin{array}{l}\text { Speech and } \\
\text { Language Room }\end{array}$ & $\begin{array}{l}\text { Cognitive challenges: executive functioning, } \\
\text { working memory, and processing speed; } \\
\text { implications for literacy teaching }\end{array}$ \\
\hline March 31, 2010 & $\begin{array}{l}\text { Wendy's } \\
\text { classroom }\end{array}$ & $\begin{array}{l}\text { ADHD and literacy challenges: language } \\
\text { functioning, reading, and written expression; } \\
\text { Wendy's case study discussion; successes, } \\
\text { challenges, and feedback about new strategy } \\
\text { implementation }\end{array}$ \\
\hline April 14, 2010 & $\begin{array}{l}\text { Danielle's } \\
\text { classroom }\end{array}$ & $\begin{array}{l}\text { Mediating behaviors associated with ADHD; } \\
\text { Danielle's case study discussion; successes, } \\
\text { challenges, and feedback about new strategy } \\
\text { implementation }\end{array}$ \\
\hline April 28, 2010 & $\begin{array}{l}\text { Connie's } \\
\text { classroom }\end{array}$ & $\begin{array}{l}\text { The attention deficit in ADHD; literacy } \\
\text { challenges and strategy implementation; } \\
\text { Connie's case study discussion; successes, } \\
\text { challenges, and feedback about new strategy } \\
\text { implementation }\end{array}$ \\
\hline May 12, 2010 & $\begin{array}{l}\text { Kathy's } \\
\text { classroom }\end{array}$ & $\begin{array}{l}\text { Talking with parents about the characteristics } \\
\text { associated with ADHD; Kathy's case study } \\
\text { discussion; successes, challenges, and feedback } \\
\text { about new strategy implementation }\end{array}$ \\
\hline May 27, 2010 & May’s classroom & $\begin{array}{l}\text { Peer observation discussion; May's case study } \\
\text { discussion; successes, challenges, and feedback } \\
\text { about new strategy implementation }\end{array}$ \\
\hline June 16, 2010 & $\begin{array}{l}\text { Wendy's } \\
\text { classroom }\end{array}$ & $\begin{array}{l}\text { Case study updates; mindfulness and self- } \\
\text { regulation; successes, challenges, and feedback } \\
\text { about new strategy implementation }\end{array}$ \\
\hline
\end{tabular}




\section{Data Sources}

To provide richness and depth, this study utilized multiple sources of data. First, data was collected through three semi-structured interviews with each participant over the period of one year. The first interviews were conducted before the CLC meetings began; the second interviews were conducted immediately after formal CLC meetings had ceased: and the final interviews were conducted in the next academic year - six months after meetings had ended. The final interviews were conducted to explore whether participants felt their experience within the CLC had led to any sustained growth or change in their perspectives and/or their literacy teaching practices over time.

Data was also collected from observations of teacher practice in the classroom as well as participant observations within each of the nine CLC meetings. Finally, participant reflection notes provided data on how they were making sense of their new knowledge and how this was guiding their actions in the classroom.

\section{Data Analysis}

I initiated my analysis after the first round of interviews and observations; I used a process of "open coding" (Corbin \& Strauss, 2007) to identify salient words, phrases, sentences and/or paragraphs that represented aspects of teachers 'experiences (i.e. lack of PD, stress, behaviors of students with ADHD, need for teaching strategies etc.). Once these were identified, they were grouped together into categories (Strauss \& Corbin, 1990), such as "stress related to teaching students with characteristics of ADHD," "use of adaptive literacy teaching strategies," and "prior professional development experiences." From my analysis, I was able to find a common set of categories for individual case studies and then compared them across participants, continuing to use the principles of constant comparison (Glaser \& Strauss, 1967). Subsequent data-gathering (e.g., additional interviews and observations) were informed by the emerging categories. In the second interview, for example, I wanted to gather more information about teachers' feelings of stress specifically related to teaching students with characteristics of ADHD. As the study progressed, I began to make connections between categories as I continued to use the constant comparative method (Glaser \& Strauss, 1967). For example, a relationship began to emerge between teachers' sense of self-efficacy related to teaching students with characteristics of ADHD and their levels of stress related to teaching this population. Finally, the core categories were established and the "storyline" (Strauss \& Corbin, 1990, p. 119) was generated. Transcripts were returned to the participants in order for them to perform member checks to establish credibility, reliability, and conformability (Lincoln \& Guba, 1985).

\section{Findings}

The findings from this study revealed that the participants' literacy teaching, particularly for students with characteristics of ADHD, was positively influenced by their participation within the CLC. Teacher learning, however, unfolded as a process. Over time, the participants re-conceptualized their understanding of their students with ADHD 
and of themselves as literacy teachers. With greater knowledge and understanding came greater compassion and increased motivation and willingness to learn about and employ supportive literacy teaching strategies for this group of students. There was a reduction in teachers' level of stress related to teaching students with ADHD as well.

\section{Literacy Teaching was Positively Influenced}

As a result of their participation in the CLC, teachers reported an increase in their knowledge about ADHD and their use of supportive strategies for teaching literacy to students with ADHD. Furthermore, each of the participants reported that it wasn't until they were in the midst of the CLC that they realized how much they did not know about ADHD and the extent to which the cognitive challenges sometimes associated with ADHD could affect their students' literacy learning. They reported being most impacted by their learning about the neurological aspects of ADHD - particularly students' difficulties with executive functioning and working memory and the literacy challenges students often experienced as a result. For example, Connie, a kindergarten teacher, described her new understanding of the executive functioning and working memory (the brain's clipboard) challenges as, "the missing puzzle piece." Immediately after the professional development meetings had finished, she said, "I now understand that the clipboard gets full and I need to break up their work. I'll give them small, short breaks during a literacy task because I know they'll be able to do more and learn more if I do." For Wendy, learning about the executive functioning and working memory challenges of her students was, "the most valuable." After learning about the importance of not overloading her students' working memories, she began to incorporate new strategies into both her reading and writing programs. In particular, she started to break up her assignments into smaller chunks and have students check in with her frequently. With more frequent milestones, her students were more likely to successfully complete their work. This is in contrast to how she typically assigned work to her students with ADHD before participating in the CLC - she tended to assign longer and more complex tasks with few check-ins along the way.

For Kathy, who had been teaching for over 18 years, the shift in her understanding and attitude came as somewhat of a surprise to her. In her initial interview before the CLC began, she lamented about her students' inattention and how this created challenges for her being able to teach them to read. Rhetorically, she asked, "how do we teach them to read if they can't pay attention?" After learning about the executive functioning challenges and the strategies that support students in this area, she felt more confident in her ability to teach literacy to her students with ADHD. For May, who had been teaching for five years, learning about the neurological aspects of ADHD gave for an opportunity to improve her understanding of her students needs and the kinds of strategies that would support their literacy learning. For example, she noticed that a few of her students were much more productive in the work because she shortened the amount of work they were required to do it one time. By chunking her students' work and allowing time-off-the-clock (i.e. regular untimed breaks in the midst of work/assignments/tests), she felt she was giving her students an opportunity to feel 
success without overwhelming them by the amount of work they needed to continue to sit still for.

For each of the other participants, there was a gradual shift in focus towards emphasizing the academic needs of their students with characteristics of ADHD. When reflecting on her understanding about students during the CLC as compared to her understanding before, Kathy was forthcoming about her shift in understanding and focus for her students with characteristics of ADHD. She said,

I know so much more now about \{students with ADHD\}. Looking back, I'm sure I was more likely to just isolate or even ignore, to sort of congratulate myself if they weren't disrupting my classroom. In the end - I can remember two kids in particular that my goal was just, they are just two kids out of 28 - and I remember thinking, if they are not disrupting the whole class, then I guess that's okay.

Connie also reported that a change in her understandings about students with ADHD contributed to how she responds to them. She said, "I went from believing that students with ADHD could control their inattention and impulsive behaviors to understanding that, for the most part, it's something they can't help." Connie felt that with more patience and compassion, and a better understanding about ADHD and its implications for literacy learning, she was implementing practices into her teaching that were positively impacting her students and their literacy learning.

\section{Teacher Learning Unfolded as a Process over Time}

The literacy professional development for these teachers of students with characteristics of ADHD did not end up beginning with a focus on the topic of literacy. Many of the participants were faced with extreme behaviors by their students with characteristics of ADHD. Not surprisingly, early discussions within the CLC focused more and mediating behaviors. It took a number of sessions before issues of behavior were sufficiently addressed enough for participants to comfortably shift their focus more toward specific issues of literacy learning and teaching. Eventually, what the participants discovered was that when they used literacy teaching strategies and materials that better supported the needs of their students, there were fewer challenging behaviors to deal with. As participants were supported through their concerns about behavior, the CLC discussions began to focus more on the details of literacy learning and literacy teaching strategies.

The progression from a focus on behavior to a more weighted focus on the details of literacy teaching and learning is illustrated in how Wendy, a third-grade teacher, spoke of her students at two points in time throughout the study. The first quote comes from a discussion amongst the participants in the second collaborative learning community meeting. Wendy was speaking about one of her students with characteristics of ADHD who rarely wrote more than a few words during writing time. She said,

He will try and find the fastest way of getting his work done. He said, 'I'm done.' 
I said, 'well that's not what you were asked to do.' And he got really mad at me and just stood there and kind of stared and I said, 'you can stand and choose not to do it or you can get it done at school or it will be homework.' He has these behaviors where I try to ignore as much as I can ignore. At the same time it comes to a point where it's, 'enough is enough. It's like WHY?'

Here, Wendy is frustrated and feeling somewhat demoralized. The strategies she had come up with in response to her student's lack of writing production was to try and coax him into the original task without changing or increasing her support and to threaten sending his writing work home as homework. Though the topic of the conversation within the group was scheduled to be centered on literacy, clearly Wendy was most consumed by her student's behavior and their continuous power struggle. In the end, she reported that the strategies she spoke about did not typically help her students produce more writing.

The second quote comes from an interview conducted with Wendy six months after the formal CLC meetings had ended. She was speaking about a comic strip unit for her literacy block that was inspired by her learning within the CLC community. The writing assignment required students to create a story in the form of a comic strip with a narrative component and illustrations. She said,

My boys with ADHD loved it. It wasn't involving a lot of writing because they could draw and they could add written details to it. But they still had to really think of the process. To this day, I still hear them begging me, "please can we do comic strips?" They were totally engaged in wanting to do it - and they were phenomenal at it. I think they loved it because they had the freedom of not having to write a full page at a time. Because I find with the ADHD kids that picking up a pencil and actually writing for some of them is such a barrier. If they don't have enough of a focus or if their clipboard \{working memory\} is overloaded, they just don't know where to start. So with the comic strips it was simple enough that they could also use pictures to tell their story. It was amazing.

This second quote illustrates quite a significant shift for Wendy. She had come to a different understanding of her students with characteristics of ADHD and their literacy needs. Early on in the CLC, Wendy was frustrated, somewhat angry, and offered relatively little additional support or scaffolding for her student. After participation within the CLC, we see that she had come to change the nature of the writing task having kept her students needs and abilities in mind. She had also come to position herself as having more expertise, seeing herself as knowledgeable in the field as she discussed the difficulties students with ADHD typically have with their working memory and writing production.

The following quote from Danielle, after their final CLC meeting, captures the nature of the shift in understanding over time by all of the participants: "The PD has allowed us a better understanding of children with ADHD from the inside out. I now start 
with a much more profound understanding of the child and go from there in thinking about the kinds of class activities and literacy instructional practices that are going be relevant for him or her."

As a result of increased knowledge about ADHD and related literacy challenges, participants reported a greater understanding of their students with ADHD. In particular, they re-conceptualized their understanding of the behaviors of their students; they became more likely to proactively respond to the conditions, settings, or academic tasks that could trigger lack of engagement or misbehavior. They also gained more complex understandings of their students' cognitive challenges and how these could affect their students' learning, performance, and ultimately their literacy learning needs. As a result of this new understanding, they reported increased feelings of compassion and more positive feelings towards their students.

Greater understanding and compassion led to increased willingness to learn about and utilize newly learned teaching strategies. The participants ultimately became more likely to differentiate their instruction for their students with characteristics of ADHD as a result. As one participants commented,

Knowing and understanding my students more has really helped me because I can see things I didn't see before. Now if a student is inattentive and can't finish their writing I can now step back and think about it related to my teaching choices and support them with the strategies I've learned, like giving breaks and chunking work more - really thinking about their needs.

The CLC's positive influence on participants' literacy teaching had sustained 6 months after the PD had formally ended. Table 3 provides examples of reported learning and change in literacy teaching practice from participants. 
Table 3

Examples of Reported Learning and Resulting Change in Practice

\begin{tabular}{lll}
\hline $\begin{array}{l}\text { Reported Behaviors of } \\
\text { Students with }\end{array}$ & $\begin{array}{l}\text { New Understanding } \\
\text { which Contributed to } \\
\text { Characteristics of ADHD } \\
\text { Chach Contributed to }\end{array}$ & $\begin{array}{l}\text { New Responses from Participants } \\
\text { as a Result of Learning within }\end{array}$ \\
$\begin{array}{l}\text { Teaching Challenges for } \\
\text { the Participants }\end{array}$ & & CLC \\
\hline
\end{tabular}

\begin{tabular}{lll}
\hline $\begin{array}{l}\text { Constant } \\
\text { fidgeting/ongoing need } \\
\text { to move }\end{array}$ & $\begin{array}{l}\text { Children with ADHD } \\
\text { often need to move more } \\
\text { in order to maintain } \\
\text { appropriate alertness }\end{array}$ & $\begin{array}{l}\text { Regular productive movement; } \\
\text { fidget toys; mindfulness exercises; } \\
\text { multiple designated sitting areas } \\
\text { (desks) to allow for regular } \\
\text { that challenge their } \\
\text { working memory }\end{array}$ \\
& & \\
&
\end{tabular}

Difficulty initiating tasks Weaknesses in working memory result in difficulty remembering Eye contact with or proximity to student before giving instructions; chunk and repeat instructions; and following instructions deliver orally and in written form; classroom buddy for instruction checks; stand still while giving directions

Frequently distracted; Weaknesses in executive Masking or dividing work into difficulty staying on task; functioning often result overwhelmed by multi- in low task adherence step tasks manageable chunks; frequent redirections (private); ongoing and frequent check-ins and incentives

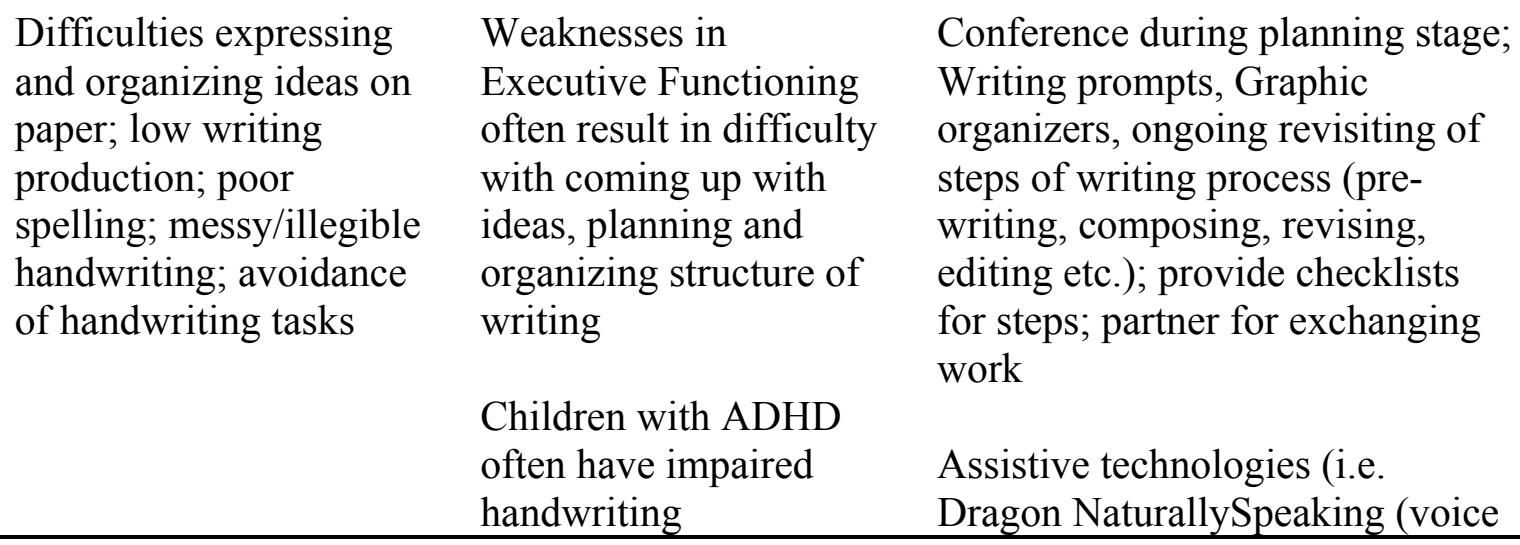


performance as a result

of fine motor challenges
Frequently miss words and important details during reading; difficulty summarizing, retelling, remembering main ideas, low comprehension
Weaknesses in working memory and processing speed often impede students with ADHD from monitoring/remembering what they read to text), Co: Writer 4000 Solo); substitute written reports with alternative ways to demonstrate knowledge (i.e. dramatic presentations, PowerPoint presentations, readers theater, audio recordings etc.)

Metacognitive strategies (i.e. notes, highlighting, underlining, sticky notes, thinking aloud, diagramming, literature logs etc.); creating a graphic representation (i.e. charts, storyboards, story maps, Venn diagrams, character webs etc.); suggesting students read aloud quietly; assistive technologies (i.e. Kurzweil- text to speech software); teaching prior, during, and after reading strategies

\section{Reconceptualization of their Understanding of Themselves as Literacy Teachers}

Each of the teachers reported feeling somewhat more confident in their ability to meet the needs of their students with characteristics of ADHD as a result of their experience in the CLC. When teachers observed their students responding positively to the new strategies they were employing, they began to view their role as literacy teachers differently. They grew to see it as part of their role to consider and understand students' cognitive/executive functioning as they planned and delivered literacy lessons for all of their students. Moreover, they began to see themselves as teachers who were more capable of effectively meeting the literacy needs of their students with ADHD than they were before their participation within the CLC. Having a newfound understanding of the literacy implications of ADHD in combination with more teaching strategies to respond to the literacy needs enabled the teachers to feel more confident in their ability to support their students at a higher level. As Danielle remarked,

I really feel much more prepared for my students with ADHD. I certainly have a fuller picture and I have some great strategies to use. I also believe that this can help me with more of my students as well. They can all benefit from what I've learned. I have a better comfort level now than I did before. 
For Wendy, having more knowledge about the literacy implications of ADHD and having the strategies to support her students have contributed to her increased confidence. Continuing to rely on her fellow CLC group members as a source of knowledge and support has also contributed to her feelings of self-efficacy. She explained:

Knowing that I have four or five other resources just within our school that I can go to and speak to and say, 'hey, look, this is happening in my class. What do you think?' Just bouncing ideas off of each other - so, having that whole experience as a group together has helped me feel more confident as a teacher.

With a new vision of themselves as literacy teachers and a noticeable increase in their confidence, the participants found that their ongoing feelings of stress associated with teaching students with characteristics of ADHD decreased.

\section{Decrease in Stress Related to Teaching Students with Characteristics of ADHD}

Prior to their participation in the CLC, each of the teachers reported experiencing higher levels of stress related to teaching students with characteristics of ADHD as compared to teachings their students without ADHD. After participating in the CLC, the participants reported a noticeable decrease in the level of teaching stress they experienced related to this population; they also admitted, however, that there would always be a certain level of stress associated with teaching students with ADHD compared to those without.

For instance, in the summer before the study took place, Wendy found out she was going to have three students with characteristics of ADHD in her class the following September. In anticipation of this, she had significantly increased amounts of stress even before school started. She worried about how she was going to meet the needs of these three students and how to ensure that the other students were not adversely affected by their behaviors. During her initial interview, Wendy admitted she was motivated to participate in the CLC, in part, because she was hoping to reduce her level of stress. She said,

I figure that maybe I can get some strategies that I can use for the students that are the main cause of my stress in the classroom. I knew early on which students I was going to have so I was already stressing about it when it wasn't even the school year beginning yet. That's why knowing the kids that I have in my class, I said yes to this opportunity.

Wendy, along with the other participants, was interviewed six months after the CLC meetings had ended; this was also the next academic school year and they each had a new group of students. At this time, Wendy admitted she would likely still have feelings of stress related to having students with characteristics of ADHD in her classroom, but less so. She reported feeling more patient and more compassionate toward her students with characteristics of ADHD and more confident to support their literacy 
learning after having had the experience within the CLC. When referring to two of her students from the new academic year who have characteristics of ADHD, she said, "I've learned to take a step back and not lose my patience with them as quickly - knowing what I know about them now." With a better understanding of how to support her students in their literacy learning, and a better sense of self-efficacy, Wendy felt a noticeable reduction in her level of stress related to teaching students with ADHD.

Although Karen reported feeling, "much more knowledgeable on how to support students with ADHD," and a lower stress level as a result, she also acknowledged the ongoing challenges. She said,

It is one of the most energy draining experiences I think the teacher has. It's hugely, hugely stressful. You spend an inordinate amount of time thinking about \{students with characteristics of ADHD\} outside of class - I do. You can, if you're not careful, put so much energy into their learning and managing them that I sometimes, if they're really hard, I can feel resentful about how much they take away from the other the other kids or if they sabotage my program.

May, Connie, and Danielle also reported lower levels of stress associated with teaching students with characteristics of ADHD after participation within the CLC. However, each of them also felt the stress would likely never completely disappear. Ultimately, however, they all reported feeling more confident in their ability to meet the literacy needs of their students with characteristics of ADHD as a result of their experiences within the CLC. This contributed to a reduction of stress over all.

\section{Discussion}

As we have seen, all five of the participants reported an increase in their knowledge about ADHD and about supportive strategies for teaching literacy to students with ADHD. This is not surprising and is in keeping with research that has found that when teachers participate in professional development, they are likely to increase their knowledge about the topic of focus (Bransford et al., 1999). As Loucks-Horsley et al. (2010) note, however, effective and successful professional development must go beyond just enhancing teacher knowledge; it must support translating newfound knowledge into practice. For the teachers in this study, knowledge acquired through the interactive, responsive, and supportive nature of the CLC contributed to a shift in their understanding and then a shift within their practice. Participants reported greater understanding and more positive feelings towards their students. In particular, all of the participants reported feeling more compassion towards students with characteristics of ADHD. This ultimately led to different ways of interacting with and instructing them, particularly in the area of literacy teaching. The importance of this cannot be underestimated, considering researchers have found that the impact of teachers expectations, attitudes, and perceptions can be a major determining factor in whether students with ADHD are successful are not (Brophy \& McCaslin, 1992; Hudson, 1997). 
The teachers within this study also gained a deeper awareness of their students' literacy learning needs and how to better support them. As previously outlined, teachers began to understand ADHD and its effects on literacy learning as much more complex than they first understood. By learning more about ADHD and its potential educational implications, participants gained a better understanding of the factors that influenced students' literacy learning - both in terms of the ways their students learned, and in the kinds of instructional strategies that supported their students best. Participants also reconceptualized their understanding of themselves as literacy teachers. As literacy teachers, they grew to see it as their role to consider working memory, executive functioning, and processing speed as they planned and delivered their literacy lessons. This has implications for any student with weaknesses in working memory. Studies indicate that children with working memory deficits, regardless of whether or not they have ADHD, tend to perform worse on tests of academic achievement than those students without such weaknesses (Gathercole \& Pickering, 2000). Furthermore, students with ADHD have a difficult time organizing and planning their writing, composing stories, constructing their written sentences and writing legibly and accurately (Martinussen et al., 2005). By gaining a better understanding of their students' general ways of thinking and learning, the participants were more able to knowledgeably choose the appropriate strategies to respond to their students' literacy needs.

In particular, participants found it helpful to learn about how students' reading and writing skills can be affected by executive functioning challenges such as weaknesses in working memory and processing speed. This helped them understand why their students may have been struggling. It also gave them the information they needed to respond more directly to their students' specific needs. For example, participants had concerns about their students' weaknesses in writing. Many of their students had low productivity and accuracy in their writing tasks. As is typical for students with characteristics of ADHD, they had difficulties communicating their thoughts on paper (Rief, 2005; Martinussen et al., 2005). In fact, in their study on learning problems in students with ADHD, Mayes, Calhoun, and Crowell (2000) found that written expression is the most common learning problem among students with ADHD. This is because it involves the integration and often simultaneous use of several skills and brain functions such as organization, spelling, fine motor, planning, self-monitoring, memory, and language (Berninger \& Abbott, 2010). These can often be areas of challenge for students with characteristics of ADHD (Martinussen et al., 2005; Mayes et al., 2000; Rief, 2005). While the participants within this study were already keenly aware of these types of difficulties for their students, they were less aware of the connections to ADHD and the ways to best offer support.

Participants came to understand literacy learning from a new perspective. They came to understand the importance of executive functioning and working memory in literacy acquisition. In order to learn to read and write, all students must utilize their executive functioning to self regulate their learning process. Weaknesses in these processes can make literacy learning more difficult and act as a barrier for many students with characteristics of ADHD (Tannock, Purvis, \& Schachar, 1993). Before 
understanding the central role executive functions play in literacy success, it was easy for teachers to misinterpret students' lack of attention as more of a behavioral matter or a matter of choice rather than a possible indication of the need for a different kind of support.

Finally, the participants identified three crucial factors related to the format and content of the CLC which ultimately contributed to its success. These elements were the opportunities to learn with and from their colleagues, participant control over the format and content of the CLC, repeated opportunities over time to reflect on and refine their practice while receiving ongoing feedback and support, and external support. The elements reported by the participants as most supportive is consistent with those identified in the relevant literature.

By participating in PD that offered opportunities for inquiry-based, constructivist approaches, the participants learned with and from their colleagues within a collaborative setting. The participants' learning was very much a social enterprise where they came to rely on the ongoing discussion, expertise, and support from one another as they continued to test their knowledge, skills, and strategies. Once exposed to new ideas (or reminded of strategies), teachers valued the sustained opportunities to consciously refine their practice along with her group members. Viewed through a social constructivist lens, the participants learned by actively interacting with the ideas and experiences of others rather than by passively taking in facts (Bruner, 1966). As Birman et al. (2000) have shown, this type of active learning encourages teachers to engage in meaningful discussion, planning, and practice. Allowing the participants to decide on both the detailed content and structure of the PD insured that the direction and content of the CLC was based on their clearly shared aims and objectives and on their ongoing realities in the classroom. As Birman et al. (2000) found, authentic connections to teachers' daily work allows for more substantial engagement with the subject matter.

\section{Limitations}

There are several potential limitations of the study. The first relates to the small number of teacher participants. Due to the small size and scope of the study, is not possible to generalize these findings to the wider teacher community. The second relates to my position as a participant in and co-constructor of the professional development meetings. Although the participants alone made decisions about the structure and detailed content of the CLC meetings, I infused my own philosophy of teaching into each meeting. By being a participant within the CLC meetings, I may also have influenced participants' thoughts about the responses I desired during the interview process. The third limitation is related to my interpretation of the data. These were no doubt informed by my personal experiences, biases, and assumptions.

\section{Conclusion}

As the findings illustrate, the participants' literacy teaching practices were positively influenced by their participation within the CLC. This positive influence came about as an interaction of factors related to their knowledge, skills, and attitudes as well 
as a reconceptualization of both their understanding of their students with characteristics of ADHD and of themselves as literacy teachers. Greater understanding and compassion led to increased motivation to learn about and utilize newly learned teaching strategies. The participants became more likely to implement adaptive and inclusive strategies as a result of acquiring a better understanding of their students with characteristics of ADHD and their needs.

Furthermore, when teachers observed their students responding positively to the new strategies they were employing, they came to see themselves as teachers who were more capable of effectively meeting the literacy needs of their students with characteristics of ADHD than they were before their participation within the CLC. They all reported enabling students to learn at higher levels as a result. Each of the participants reported this resulted in a sustained increase in their sense of self-efficacy and a noticeable reduction in their levels of stress related to teaching students with characteristics of ADHD. The CLC's positive influence on participants' literacy teaching had sustained 6 months after the PD had formally ended and into the next academic year.

Findings from this study strongly suggest the need for specific preparation for teachers on the most up-to-date adaptive and inclusive literacy teaching strategies for students with ADHD. Findings from this study may be used to help catalyze quality PD in the area of literacy teaching for general classroom teachers, which may ultimately impact teacher and student experiences positively. Teachers need to be supported at school to develop more collaborative and research informed approaches to their PD. Professional development needs to involve teachers in more active and collaborative forms of learning with a clear link to research and classroom teaching and learning. It also needs to emphasize continuous and longer-term professional learning. Teachers need to be consulted about the kinds of professional development that are most appropriate for the realities of their classroom, and they need ongoing support to develop and refine their literacy teaching practice over time.

\section{References}

American Psychiatric Association. (2013). Diagnostic and statistical manual of mental disorders (5th ed). Washington, DC: American Psychiatric Association.

Barbaresi, W. J., \& Olsen, R. D. (1998). An ADHD educational intervention for elementary school teachers: A pilot study. Developmental and Behavioral Pediatrics, 19, 94-100.

Barkley, R.A. (2012). Executive Functions: What They Are, How They Work, and Why They Evolved. New York: Guilford.

Barkley, R.A. (2013). Taking Charge of ADHD: The Complete Authoritative Guide for Parents, 3rd ed. New York: Guilford.

Birman, B. F., Desimone, L., Garet, M., \& Porter, A. (2000). Designing professional development that works. Educational Leadership, 57(8), 28-33.

Berninger, V. W., \& Abbott, R. D. (2010). Listening comprehension, oral expression, reading comprehension, and written expression: Related yet unique language 
systems in grades 1, 3, 5, and 7. Journal of Educational Psychology, 102(3), 635651.

Bos, C. S., Nahmias, M., \& Urban, M. A. (1997). Implementing interactive professional development in a workshop course on educating students with ADHD. Teacher Education and Special Education, 20, 132-145.

Bransford, J., Brown, A. L., \& Cocking, R. R. (Eds.). (1999). How people learn: Brain, mind, experience, and school. Washington DC: National Academy Press for National Research Council.

Breslau, J., Miller, E., Breslau, N., Bohnert, K., Lucia, V., \& Schweitzer, J. (2009). The impact of early behavior disturbances on academic achievement in high school. Pediatrics, 123, 1472-1476.

Brophy, J., \& McCaslin, M. (1992). Teachers'reports of how they perceive and cope with problems students. The Elementary School Journal, 93, 3-67.

Bruner, J. S. (1966). Toward a theory of instruction. Cambridge MA: Harvard. University Press.

Bussing, R., Gary, F. A., Leon, C. E., Wilson Garvan, C., \& Reid, R. (2002). General classroom teachers' information and perceptions of attention deficit hyperactivity disorder. Behavioral Disorders, 27(4), 327-339.

Butler, D. \& Leyton, S. (2012). Collaborative Inquiry in Teacher Professional Development . Teaching and Teacher Education: An International Journal of Research and Studies 28.8 1206-1220.

Cain, K. \& Bignell, S. (2014). Reading and listening comprehension and their relation to inattention and hyperactivity . British Journal of Educational Psychology. Volume 84 (1), 108-124.

Caroll, J., Maughan, B., Goodman, R., \& Meltzer H. (2005). Literacy difficulties and psychiatric disorders: Evidence for core morbidity. Journal of Child Psychology and Psychiatry, 46, 524-532.

Corbin, J. M., \& Strauss, A. L. (2007). Basics of qualitative research: Techniques and procedures for developing grounded theory (3rd ed.). Los Angeles, CA: Sage.

Creswell, J. (1998). Qualitative inquiry and research design: Choosing among five traditions. Thousand Oaks, CA: Sage.

Currie, J., \& Stabile, M. (2006). Child mental health and human capital accumulation: The case of ADHD. Journal of Health Economics, 25, 1084-1118.

Darling-Hammond, L., Banks, J., Zumwalt, K., Gomez, L., Gamoran-Sherin, M., Griesdorn, J., \& Finn, L.-E. (2005). Educational goals and purposes. In L. Darling-Hammond \& J. Bransford (Eds.), Preparing teachers for a changing world: What teachers should learn and be able to do (pp. 169-200). San Francisco, CA: Jossey-Bass.

Desimone, L., Porter, A., Garet, M., Yoon, K., \& Birman, B. (2002). The effects of professional development on teachers instruction: Results from a three year longitudinal study. Educational Evaluation and Policy Analysis, 24, 81-112.

Dewey, J. (1938/1997). Experience and education. New York: Simon \& Schuster. 
DuPaul G., \& Stoner, G. (2003). ADHD in the schools: Assessment and intervention strategies. New York, NY: Guilford Press.

Fletcher, J., \& Wolfe, B. (2008). Child mental health and human capital accumulation: The case of ADHD revisited. Journal of Health Economics, 27, 794-800.

Gathercole, S. E., \& Pickering, S. J. (2000). Assessment of working memory in six- and seven-year-old children. Journal of Educational Psychology, 92, 377-390.

Ghelani, K., Sidhu,R., Jain, U., \& Tannock, R. (2004). Reading comprehension and reading related abilities in adolescents with reading disabilities and attentiondeficit/hyperactivity disorder. Dyslexia, 10, 364-384.

Glaser, B. G., \& Strauss, A. L. (1967). The discovery of grounded theory: Strategies for qualitative research. Chicago, IL: Aldine.

Hargreaves, D. H. (1967). Social relations in the secondary school. London, England: Routledge and Keegan Paul.

Hargreaves, A., \& Fullan, M. G. (Eds.). (1992). Understanding teacher development. London, England: Cassell.

Harjacher, J., Roberts, N., \& Merrill, K. (2006). Classwide interventions for students with ADHD. Teaching Exceptional Children, 39, 6-12.

Hudson, A. (1997).Classroom instruction for children with ADHD. Australian Journal of Early Childhood, 22, 24-28.

Jerome, L., Gordon, M., \& Hustler, P. (1994). Comparison of American and Canadian teachers' knowledge and attitudes towards attention deficit hyperactivity disorder (ADHD). Canadian Journal of Psychiatry, 39, 563-566.

Jones, K., Daley, D., Hutchings, J., Bywater, T., \& Eames, C. (2008). Efficacy of the Incredible Years Programme as an early intervention for children with conduct problems and ADHD: Long-term follow-up. Child: Care, Health and Development, 34(3), 380-390.

Jordan, A., Schwartz, E., \& McGhie-Richmond, D. M. (2009). Preparing teachers for inclusive classrooms. Teaching and Teacher Education, 25, 535-542.

Katz, L., Brown, F., Roth, R., Beers, S. (2011). Processing Speed and Working Memory Performance in Those with Both ADHD and a Reading Disorder Compared with Those with ADHD Alone. Archives of Clinical Neuropsychology . Volume 26 (5), 425-433.

Kos, J. M., Richdale, A. L., \& Hay, D. A. (2006). Children with attention deficit hyperactivity disorder and their teachers: A review of the literature. International Journal of Disability, Development and Education, 53(2), 147-160.

Leko, M., \& Brownell, M. (2009). Crafting quality professional development for special educators: What school leaders should know. Teaching Exceptional Children, 42, 64-70.

Levy, F., Hay, D., McStephen, M., Wood, C., \& Waldman, I. (1997). Attention deficit hyperactivity disorder: a category or a continuum? Genetic analysis of a largescale twin study. Journal of American Academy of Child Adolescent Psychiatry. 36 (6), 737-744.

Lincoln, Y. S., \& Guba, E. G. (1985). Naturalistic inquiry. Beverly Hills, CA: Sage. 
Loucks-Horsley, S., Love, N., Stiles, K., Mundry, S., \& Hewson, P. (2010). Designing professional development for teachers of science and mathematics. Thousand Oaks, CA: Corwin Press.

Lytle, S. L., Belzer, A., \& Reumann, R. (1992). Invitations to inquiry: Rethinking staff development in adult literacy education. (Technical Report TR92-2).

Philadelphia: National Center on Adult Literacy.

Martinussen, R., Tannock, R., \& Chaban, P. (2011). Teachers reported use of instructional and behavioral management practices for students with behavior problems: Relationship to role and level of training in ADHD. Child Youth Care Forum, 40, 193-210.

Martinussen, R., Tannock, R., Chaban, P., McInnes, A., Ferguson, B. (2006). Increasing awareness and understanding of attention deficit hyperactivity disorder (ADHD) in education to promote better academic outcomes for students with ADHD. Exceptionality Education Canada, 16, 107-128.

Martinussen, R.L., R. Tannock, A. McInnes, \& P. Chaban. (2005). Teacher for Success: TeachADHD Teachers Resource Manual. Toronto: TV Ontario and Sick Kids Hospital.

Mayes, S., Calhoun, S., Crowell, E. (2000). Learning disabilities and ADHD: overlapping spectrum disorders. Journal of Learning Disabilities. 33 (5). 417-424.

Merriam, S. (2009). Qualitative research: A guide to design and implementation. San Francisco, CA: Jossey Bass.

Morrow, R., Garland, J., Wright, J., Maclure, M., Taylor, S., \& Dormuth, C. (2012). Influence of relative age on diagnosis and treatment of attention deficit/hyperactivity disorder in children. Canadian Medical Association Journal, 184(7), 755-762.

Opfer, V. D., \& Pedder, D. (2011). Conceptualizing teacher professional learning. Review of Educational Research, 81(3), 376-407.

Polderman, T., Derks, E., Hudziak, J., Verhulst, F., \& Boomsma, D. (2007). Across the continuum of attention skills: a twin study of the SWAN ADHD rating scale. Journal of Child Psychology and Psychiatry. 48 (11), 1080-1087.

Punch, F. (2009). Introduction to research methods in education. London, England: Sage.

Reif, S.F. (2005). How to Reach and Teach Children with ADD/ADHD: Practical Techniques, Strategies, and Interventions. 2nd ed. San Francisco: Jossey-Bass.

Rogers, M., Wiener, J. Marton, I. \& Tannock, R. (2009) Academic parental involvement in children with and without attention-deficit/hyperactivity disorder. Journal of School Psychology, 47, 167-185.

Rush, C., \& Harrison, P. (2008). Ascertaining teachers' perceptions of working with adolescents with attention deficit/hyperactivity disorder. Educational Psychology in Practice, 24(3), 207-223. (ERIC Document Reproduction Service No. EJ815938)

Schechter, C., \& Ganon, S. (2012). Learning from Success: Exploring the Sustainability of a Collaborative Learning Initiative. Journal of Educational Administration $50.6,732-752$. 
Sesma, H.W., Mahone, E.M., Levine, T., Eason, S., \& Cutting, L. (2009). The contribution of executive skills to reading comprehension. Child Neuropsychology, 15, 232-246.

Tannock, R. (2007). The educational implications of attention deficit hyperactivity disorder. What works? Research into practice. Toronto, Ontario, Canada: Ontario Ministry of Education, The Literacy and Numeracy Secretariat.

Tannock, R., \& Brown, T. E. (2000). Attention deficit disorders with learning disorders in children and adolescents. In T. E. Brown (Ed.), Attention deficit disorders and comorbidities in children, adolescents, and adults (pp. 231-295) Washington, DC: American Psychiatric Press.

Tannock, R., Purvis, K. L., \& Schachar, R. (1993). Narrative abilities in children with attention deficit hyperactivity disorder and normal peers. Journal of Abnormal Child Psychology, 21, 103-117.

Vygotsky, L. S. (1986). The genetic roots of thought and speech. In A. Kozulin (Trans. \& Ed.), Thought and language (pp. 68-95). Cambridge, MA: MIT Press.

Vygotsky, L. S. (1978). Mind in society: The development of higher psychological processes. Cambridge, MA: Harvard University Press.

Wenger, E. (1998). Communities of practice: Learning, meaning, and identity. Cambridge, England: University Press.

Westling, D. (2010). Teachers and challenging behaviors: Knowledge, views, and practices. Remedial and Special Education, 31, 48-63.

Yin, R. (2011). Case study research: Design and methods. Thousand Oaks, CA: Sage.

\section{Biography}

Dr. Shelley Murphy is a lecturer in the Master of Teaching Program in the Department of Curriculum, Teaching and Learning at the Ontario Institute for Studies in Education of the University of Toronto. She teaches Introduction to Special Education and Adaptive Instruction and Curriculum and Teaching in Literacy. Her doctoral research investigated teachers' experiences related to learning to improve their literacy instruction for students with characteristics of ADHD. Her research interests include: language and literacy, inclusive teaching practices; teacher education and development; and mindfulness in education. Currently, she is investigating the aspects or qualities of teacher education and development programs, which are conducive to preparing teachers to effectively support students with special education/diverse learning needs. Her research and teaching are informed by her previous work as an elementary classroom teacher, school literacy specialist, and literacy consultant. 